\title{
A Systematic Review of the Zinc Concentrations in the Prostate Fluid of Normal and Inflamed Gland
}

\author{
Vladimir Zaichick ${ }^{1}$, Sofia Zaichick ${ }^{2}$ \\ ${ }^{1}$ Radionuclide Diagnostics Department, Medical Radiological Research Centre, Obninsk, 249036, Russia \\ ${ }^{2}$ Laboratory of Dr. Gabriela Caraveo Piso, Feinberg School of Medicine, Northwestern University, Chicago, \\ IL 60611-4296, USA
}

Correspondence should be addressed to Vladimir Zaichick; vzaichick@gmail.com

Received 30 November 2019;

Accepted 18 December 2019;

Published 31 December 2019

\begin{abstract}
Background and objective: the prostate gland is subject to various disorders and of them chronic prostatitis (CP) is a complex disease. Various studies indicate some discrepancies regarding zinc $(\mathrm{Zn})$ levels in prostatic fluid of normal and inflamed glands. The present study evaluated by systematic analysis the published data for Zn levels analyzed in expressed prostatic fluid (EPF) of normal and inflamed glands. Methods: The present systematic analysis included 25 studies, all of which were published in the years from 1961 to 2018 and selected by searching the databases Scopus, PubMed, MEDLINE, ELSEVIER-EMBASE, Cochrane Library, and the Web of Science. The articles were analyzed and "Median of Means" and "Range of Means" were used to examine heterogeneity of $\mathrm{Zn}$ concentrations in two groups of subjects - apparently healthy men "N" and patients with prostatitis "P". Moreover, using the ratios of prostatic fluid Zn in "P" group to prostatic fluid Zn in "N" group $(\mathrm{ZnP} / \mathrm{ZnN})$ obtained (or calculated by us) in the reviewed studies, "Median of Means" and "Range of Means" for these ratios were found. The objective analysis was performed on data from the 25 studies, with total 285 subjects in "P" group and more than 900 subjects in "N" group. Results: The range of means of $\mathrm{Zn}$ concentration reported in the literature for normal EPF varies widely from $47.1 \mathrm{mg} / \mathrm{L}$ to $825 \mathrm{mg} / \mathrm{L}$ with median of means $501 \mathrm{mg} / \mathrm{L}$. The range of means of $\mathrm{Zn}$ concentration for EPF of untreated prostatitis varies also widely from $56 \mathrm{mg} / \mathrm{L}$ to 491 $\mathrm{mg} / \mathrm{L}$, with median of means $268 \mathrm{mg} / \mathrm{L}$. Thus, the obtained median of means for $\mathrm{Zn}$ concentration in normal human prostatic fluid is about two times higher than median of mean values of the element content in EPF of inflamed prostate. In other words, the analysis of 25 studies with discordant data regarding prostatic fluid concentration of $\mathrm{Zn}$ demonstrated that there is a significantly diminished concentration of $\mathrm{Zn}$ in $\mathrm{EPF}$ of patients with prostatitis compared to controls. Conclusion: There is a significant relationship between lowered $\mathrm{Zn}$ concentrations in prostatic fluid and prostatitis, but because of small sample size and high data heterogeneity, we recommend other primary studies.
\end{abstract}

Keywords: Prostate, prostatitis, expressed prostatic fluid, trace elements, zinc

\section{Introduction}

The prostate gland is subject to various disorders and of them chronic prostatitis $(\mathrm{CP})$ is a complex disease. $\mathrm{CP}$ causes a range of symptoms including pain, urinary problems, such as urgency and frequency, reduced quality of life and sexual dysfunction ${ }^{[1.2]}$. Accounting for more than $90 \%$ of urological outpatient cases seen, $\mathrm{CP}$ remains one of the most common urologic disorders in men younger than 50 years old ${ }^{[3]}$. Etiology of CP is not fully understood and treatment is frequently unsuccessful ${ }^{[1-3]}$. Fragmentary epidemiological evidence indicates that risk factors such as infection, autoimmunity, inflammation, excessive amounts of tumor-related proteins, imbalance of hormones and nutritionrelated variables, including $\mathrm{Zn}$ and some other trace elements (TEs) as micronutrients, may be associated with $\mathrm{CP}^{[4]}$.

In our previous studies the significant involvement of $\mathrm{Zn}, \mathrm{Ca}$, $\mathrm{Mg}, \mathrm{Rb}$ and some other TEs in the function of the prostate was found ${ }^{[5-15]}$. Moreover, it was demonstrated that the changes of $\mathrm{Zn}$ content and levels of $\mathrm{Zn} / \mathrm{TE}$ ratio in the prostate tissue can be used as biomarkers of prostate disorders ${ }^{[16-25]}$.
One of the main functions of the prostate gland is the production of prostatic fluid ${ }^{[26]}$. It contains a high concentration of $\mathrm{Zn}$ and elevated levels of $\mathrm{Ca}, \mathrm{Mg}, \mathrm{Rb}$, and some other TEs, in comparison with levels in serum and other human body fluids. The first finding of remarkably high levels of $\mathrm{Zn}$ in human expressed prostatic fluid (EPF) was reported in the early $1960 \mathrm{~s}^{[27]}$. After analyzing EPF expressed from the prostates of 8 apparently healthy men, aged 25-55 years, it was found that $\mathrm{Zn}$ concentrations varied from 300 to $730 \mathrm{mg} / \mathrm{L}$. After this finding several investigators suggested that the measurement of $\mathrm{Zn}$ levels in EPF may be useful as a marker of abnormal prostate secretory function ${ }^{[28,29]}$. This suggestion promoted more detailed studies of the $\mathrm{Zn}$ concentrations in the EPF of healthy subjects and in those with different prostatic diseases, including $\mathrm{CP}^{[29,30]}$.

For humans, $\mathrm{Zn}$ is an essential nutritional TE, especially in terms of proteins and nucleic acids metabolism. It is required for the catalytic activity of at least 300 enzymes, and is involved in the human immune system, in tissue repair, and in DNA syntheses. There are a lot of data on the subject. For example its role in cell immunity and as an antioxidant has recently been reviewed ${ }^{[31-35]}$. 
However, the exact role of $\mathrm{Zn}$ in normal and pathophysiology of the prostate is until now unknown.

The effects of TEs are related to concentration and recorded observations range from a deficiency state, to function as biologically essential components, to an unbalance when excess of one element interferes with the function of another, to pharmacologically active concentrations, and finally to toxic and even life-threatening concentrations ${ }^{[36,37]}$. Oxidative stress has significant involvement in the pathogenesis of $\mathrm{CP}^{[38]}$. Oxidative stress is a result of the imbalance between reactive oxygen species and antioxidants, including $\mathrm{Zn}$ and some other TE, in the body that can cause tissue and organ damage. In this context, the role in prostate disorders has been associated with non-adequate $\mathrm{Zn}$ content in tissues and fluid of the gland for a long time ${ }^{[34,36-40]}$.

Several studies have reported the $\mathrm{Zn}$ content in EPF of normal and inflamed gland ${ }^{[29,30,41-61]}$. But the findings of various studies indicate some discrepancies. One researcher has demonstrated a great decrease (almost 10 times) of $\mathrm{Zn}$ concentration in EPF of patients with CP compared to controls ${ }^{[56]}$, while others have not found the statistically significant effect $^{[29,30,61]}$. Thus, further investigation has been considered necessary to provide clearer hypothesis about the role of $\mathrm{Zn}$ in $\mathrm{CP}$.

The present study addresses the significance of prostatic fluid $\mathrm{Zn}$ levels in CP. Therefore, we systematically reviewed the available literature and performed a statistical analysis to evaluate the effect of inflammation on prostatic fluid $\mathrm{Zn}$ concentration, which may shed valuable insight into the diagnosis of $\mathrm{CP}$.

\section{Materials and Methods}

\section{Data sources and search strategy}

Aiming at finding the most relevant articles for this review, a thorough comprehensive web search was conducted from Scopus, PubMed, MEDLINE, ELSEVIER-EMBASE, Cochrane Library, and the Web of Science databases between 1961 to November 2019, using the key words: prostatitis, trace elements, Zn concentration, expressed prostatic fluid, and their combination. For example, the search terms for $\mathrm{Zn}$ concentration were: ' $\mathrm{Zn}$ concentration', 'Zn content', 'Zn level', 'prostatic fluid $\mathrm{Zn}$ ' and "Zn of expressed prostatic fluid", while those for prostatitis were: 'chronic prostatitis', 'acute prostatitis', and 'prostate inflammation'. The language was not restricted. The titles from the search results were evaluated closely and determined to be acceptable for potential inclusion criteria. Also, references from the selected articles were examined as further search tools. Relevant studies noted in the reference lists of each selected article were also evaluated for inclusion.

\section{Eligibility criteria}

Inclusion criteria: Studies were included if patients met the diagnostic criteria of prostatitis. The controls were healthy human males with no history or evidence of andrologia or urologic disease. Zinc was detected in samples of EPF.

Exclusion criteria: Studies were excluded if they were case reports. Studies involving patients with prostatitis that were undergoing $\mathrm{Zn}$ supplementation therapy were also excluded.

\section{Data extraction}

A standard extraction of data was applied, and the following available variables were extracted from each paper for two groups of subjects with normal "N" and inflamed "P" prostate: method of $\mathrm{Zn}$ determination, number and age of health persons and patients, samples preparing, means and medians of $\mathrm{Zn}$ concentrations, standard deviations of means, range of $\mathrm{Zn}$ concentrations, and statistical difference of means. Abstracts and full articles were reviewed independently by two of the authors, and if the results were different, papers were checked jointly until the differences were resolved.

\section{Statistical analysis}

Studies were combined based on means of $\mathrm{Zn}$ concentrations in EPF. The articles were analyzed and "Median of Means" and "Range of Means" were used to examine heterogeneity of $\mathrm{Zn}$ concentrations in two groups of subjects - "N" and "P". Moreover, using the ratios of prostatic fluid $\mathrm{Zn}$ in "P" group to prostatic fluid $\mathrm{Zn}$ in "N" group ( $\mathrm{ZnP} / \mathrm{ZnN}$ ) obtained (or calculated by us) in the reviewed studies, "Median of Means" and "Range of Means" for these ratios were also found. The objective analysis was performed on data from the 25 studies, with total 285 subjects in "P" group and more than 900 subjects in "N" group. In addition, two subgroups of data from group "N" were used to evaluate the difference between results obtained by destructive and nondestructive analytical methods.

\section{Results}

A total of 1885 unduplicated studies were identified. Among them 25 studies were ultimately selected according to eligibility criteria, including 25 studies that investigated $\mathrm{Zn}$ concentrations in EPF of normal prostate (Table 1) and 11 studies that investigated $\mathrm{Zn}$ concentrations in EPF of both normal and inflamed prostate (Table 2). After discussion, all reviewers were in agreement to include all 25 papers.

Table 1: Reference data of $\mathrm{Zn}$ concentration in normal human prostatic fluid (group "N")

\begin{tabular}{|c|c|c|c|c|c|c|}
\hline \multirow[b]{2}{*}{ Reference } & \multirow[b]{2}{*}{ Method } & \multirow[b]{2}{*}{$\mathbf{n}$} & \multirow{2}{*}{$\begin{array}{l}\text { Age, years } \\
\text { M(Range) }\end{array}$} & \multirow{2}{*}{$\begin{array}{l}\text { Samples } \\
\text { preparing }\end{array}$} & \multicolumn{2}{|l|}{ Zn, mg/L } \\
\hline & & & & & $\mathrm{M} \pm \mathrm{SD}(\mathrm{Med})$ & Range \\
\hline Birnbaum et al $1961^{[41]}$ & $\mathrm{XRF}$ & - & - & Intact & 490 & - \\
\hline Mackenzie et al $1962^{[42]}$ & $\mathrm{XRF}$ & 8 & $37(25-55)$ & Intact & $490 \pm 130$ & $265-666$ \\
\hline Burgos, 1974 ${ }^{[43]}$ & - & - & - & - & 47.1 & - \\
\hline Marmar et al $1975^{[44]}$ & AAS & 33 & - & $\mathrm{AD}$ & $451 \pm 215$ & - \\
\hline Anderson \& Fair, 1976 ${ }^{[45]}$ & AAS & 15 & $50(30-74)$ & $\mathrm{AD}$ & $352 \pm 190$ & - \\
\hline Fair et al $1976^{[46]}$ & AAS & 49 & $52(24-76)$ & $\mathrm{AD}$ & $455 \pm 208$ & $150-1000$ \\
\hline Paz et al $1977^{[47]}$ & AAS & 53 & - & $\mathrm{AD}$ & $299 \pm 202$ & - \\
\hline Fair \&Cordonnier $1978^{[48]}$ & AAS & 63 & $52(24-76)$ & $\mathrm{AD}$ & $455 \pm 208$ & - \\
\hline Homonnai et al $1978^{[49]}$ & AAS & 12 & - & $\mathrm{AD}$ & $335 \pm 45$ & - \\
\hline Marmar et al $1980^{[50]}$ & AAS & 33 & - & $\mathrm{AD}$ & $451 \pm 215$ & - \\
\hline${\text { Zaichick et al } 1981^{[29]}}^{[29}$ & EDXRF & 15 & - & Intact & $580 \pm 183$ & - \\
\hline Zaneveld \& Tauber $1981^{[51]}$ & - & - & - & - & 50.3 & - \\
\hline
\end{tabular}




\begin{tabular}{|c|c|c|c|c|c|c|}
\hline Kavanagh et al $1982^{[52]}$ & AAS & 35 & 49.2 & $\mathrm{AD}$ & 580 & - \\
\hline Kavanagh $1983^{[53]}$ & AAS & 152 & - & $\mathrm{AD}$ & $595 \pm 222$ & $52-1308$ \\
\hline Zaichick et al $1996^{[30]}$ & EDXRF & 22 & $49(22-75)$ & Intact & $590 \pm 210$ & $291-1118$ \\
\hline Mo et al $2000^{[54]}$ & ICPAES & 25 & $57.4 \pm 6.8$ & $\mathrm{AD}$ & 305 & $243-379$ \\
\hline Cai et al. $2002^{*[55]}$ & AAS & 22 & - & $\mathrm{AD}$ & $220 \pm 85$ & - \\
\hline Gómez et al 2007 ${ }^{[56]}$ & AAS & 10 & $44(40-62)$ & $\mathrm{AD}$ & $519 \pm 374$ & $131-1242$ \\
\hline Costello \& Franklin $2009^{[57]}$ & EDXRF & 24 & - & Intact & 588 & - \\
\hline Zhuang et al. 2009* ${ }^{[55}$ & AAS & 20 & - & $\mathrm{AD}$ & $802 \pm 39$ & - \\
\hline He et al. $2013^{* 55]}$ & AAS & 40 & - & $\mathrm{AD}$ & $825 \pm 71$ & - \\
\hline Zaichick \& Zaichick $2018^{[58]}$ & EDXRF & 41 & $18-82$ & Intact & $573 \pm 202(552)$ & $253-948$ \\
\hline & & 13 & $28(18-40)$ & Intact & $501 \pm 47$ & - \\
\hline & & 38 & $59(41-82)$ & Intact & $598 \pm 34$ & - \\
\hline Zaichick \& Zaichick $2018^{[59]}$ & EDXRF & 42 & $31-75$ & Intact & $559 \pm 204(549)$ & $253-948$ \\
\hline Zaichick \& Zaichick 2018 ${ }^{[60]}$ & EDXRF & 38 & $41-82$ & Intact & $598 \pm 207(560)$ & $253-948$ \\
\hline Zaichick \& Zaichick 2018 ${ }^{[61]}$ & EDXRF & 38 & $41-82$ & Intact & $598 \pm 207(560)$ & $253-948$ \\
\hline \multicolumn{2}{|l|}{ Median of means, mg/L } & \multicolumn{5}{|l|}{501} \\
\hline \multicolumn{2}{|l|}{ Range of means $\left(M_{\min }-M_{\max }\right), \mathrm{mg} / \mathrm{L}$} & \multicolumn{5}{|c|}{$47.1-825$} \\
\hline \multicolumn{2}{|l|}{ Ratio $\mathrm{M}_{\max } / \mathrm{M}_{\min }$} & \multicolumn{5}{|c|}{$(825 / 47.1)=17.5$} \\
\hline
\end{tabular}

* Data of Chinese researches taken from the review Cui et al 2015

$M$ - arithmetic mean, $S D$ - standard deviation of mean, Med - median, XRF - X-ray fluorescence, AAS - atomic absorption spectrophotometry, EDXRF - energy dispersive X-ray fluorescence, ICPAES - inductively coupled plasma atomic emission spectrometry, AD - acid digestion

Tables 1 and 2 summarize general data from the 25 studies. The retrieved studies involved 285 patients with prostatitis and more than 900 normal controls. The ages of subjects in "N" group were available for 14 studies and ranged from $18-82$ years. The ages of subjects in "P" group were available for 5 studies and ranged from 25-72 years. The mean ages of subjects in the control and patient groups were available for 10 and 4 studies, respectively. The information about analytical method was available for 23 studies. Fourteen studies determined $\mathrm{Zn}$ concentration by the destructive analytical methods: thirteen using AAS (atomic absorption spectrophotometry) and one using ICPAES (inductively coupled plasma atomic emission spectrometry). Nine studies detected $\mathrm{Zn}$ concentration in EPF by the non-destructive analytical methods, such as X-ray fluorescence analysis (XRF, 2 studies) and energy dispersive $\mathrm{X}$-ray fluorescence analysis (EDXRF, 7 studies). Table 3 and 4 present data of $\mathrm{Zn}$ concentration in EPF of normal prostates obtained by the destructive and non-destructive analytical methods, respectively.

Table 2: Reference data of $\mathrm{Zn}$ concentration in human prostatic fluid of normal $(\mathrm{N})$ and inflamed (P) gland

\begin{tabular}{|c|c|c|c|c|c|c|}
\hline Reference & Method & $\mathbf{n}$ & $\begin{array}{l}\text { Age, years } \\
\text { M(Range) }\end{array}$ & $\begin{array}{l}\text { Group } \\
\text { "N" or "P" }\end{array}$ & $\begin{array}{l}\mathrm{Zn}, \mathrm{mg} / \mathrm{L} \\
\mathrm{M} \pm \mathrm{SD}\end{array}$ & $\mathbf{Z} \mathbf{n}_{\mathrm{P}} / \mathbf{Z} \mathbf{n}_{\mathrm{N}}$ \\
\hline \multirow[t]{2}{*}{ Anderson\&Fair, $1976^{[45]}$} & AAS & 15 & $50(30-74)$ & $\mathrm{N}$ & $352 \pm 190+$ & 0.341 \\
\hline & & 13 & $51(31-67)$ & $\mathrm{P}$ & $120 \pm 90$ & \\
\hline \multirow[t]{2}{*}{ Fair et al $1976^{[46]}$} & AAS & 91 & $52(24-76)$ & $\mathrm{N}$ & $455 \pm 208+$ & 0.319 \\
\hline & & 15 & - & $\mathrm{P}$ & $145 \pm 62$ & \\
\hline \multirow[t]{2}{*}{ Fair\&Cordonnier $1978^{[48]}$} & AAS & 63 & $52(24-76)$ & $\mathrm{N}$ & $455 \pm 208+$ & 0.264 \\
\hline & & 10 & $54(37-60)$ & $\mathrm{P}$ & $120 \pm 101$ & \\
\hline \multirow[t]{2}{*}{ 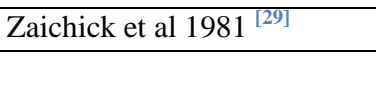 } & EDXRF & 15 & - & $\mathrm{N}$ & $580 \pm 183$ & 0.676 \\
\hline & & 18 & - & $\mathrm{P}$ & $392 \pm 284$ & \\
\hline \multirow[t]{2}{*}{ Kavanagh et al $1982^{[52]}$} & AAS & 35 & 49.2 & $\mathrm{~N}$ & $580+$ & 0.153 \\
\hline & & 29 & 49.4 & $\mathrm{P}$ & 88.9 & \\
\hline \multirow[t]{2}{*}{ Zaichick et al $1996^{[30]}$} & EDXRF & 22 & $49(22-75)$ & $\mathrm{N}$ & $590 \pm 210$ & 0.771 \\
\hline & & 28 & $49(25-72)$ & $\mathrm{P}$ & $455 \pm 317$ & \\
\hline \multirow[t]{2}{*}{ Cai et al. $2002 *^{[55]}$} & AAS & 22 & - & $\mathrm{N}$ & $220 \pm 85+$ & 0.700 \\
\hline & & 30 & - & $\mathrm{P}$ & $154 \pm 90$ & \\
\hline \multirow[t]{2}{*}{ 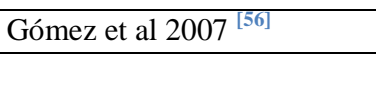 } & AAS & 10 & $44(40-62)$ & $\mathrm{N}$ & $519 \pm 374+$ & 0.108 \\
\hline & & 10 & $51(47-54)$ & $\mathrm{P}$ & $56 \pm 24$ & \\
\hline \multirow[t]{2}{*}{ Zhuang et al. $2009 *{ }^{[55]}$} & AAS & 20 & - & $\mathrm{N}$ & $802 \pm 39+$ & 0.612 \\
\hline & & 52 & - & $\mathrm{P}$ & $491 \pm 46$ & \\
\hline \multirow[t]{2}{*}{ He et al. $2013^{*[55]}$} & AAS & 40 & - & $\mathrm{N}$ & $825 \pm 71+$ & 0.593 \\
\hline & & 47 & - & $\mathrm{P}$ & $489 \pm 49$ & \\
\hline \multirow[t]{2}{*}{ Zaichick\&Zaichick $2018^{[6]]}$} & EDXRF & 42 & $31-75$ & $\mathrm{~N}$ & $559 \pm 204+$ & 0.683 \\
\hline & & 33 & $37-65$ & $\mathrm{P}$ & $382 \pm 275$ & \\
\hline \multirow[t]{2}{*}{ Group "N" } & \multicolumn{4}{|c|}{ Median of Means (mg/L) } & \multicolumn{2}{|l|}{559} \\
\hline & \multicolumn{4}{|c|}{ Range of Means(mg/L) } & \multicolumn{2}{|l|}{$220-825$} \\
\hline \multirow[t]{2}{*}{ Group "P" } & \multicolumn{4}{|c|}{ Median of Means (mg/L) } & \multicolumn{2}{|l|}{268} \\
\hline & \multicolumn{4}{|c|}{ Range of Means (mg/L) } & \multicolumn{2}{|l|}{$56-491$} \\
\hline Ratio $\mathrm{Zn}_{\mathrm{P}} / \mathrm{Zn}_{\mathrm{N}}$ & \multicolumn{4}{|c|}{ Median of Means } & \multicolumn{2}{|l|}{0.593} \\
\hline
\end{tabular}


* Data of Chinese researches taken from the review Cui et al 2015

+ Statistically significant differences between group " $N$ " and " $P$ "

$M$ - arithmetic mean, $S D$ - standard deviation of mean, AAS - atomic absorption spectrophotometry, EDXRF - energy dispersive X-ray fluorescence.

\section{Discussion}

Samples of EPF are much more available for study than prostate tissue and can be obtained without damaging the prostate gland. Information about $\mathrm{Zn}$ concentrations in prostatic fluid in different prostatic diseases is of obvious interest, not only to more profoundly understand the etiology and pathogenesis of prostatic diseases, but also for their diagnosis, including prostatitis ${ }^{[29,30,55,59-}$ ${ }^{61]}$. Thus, it dictates a need in reliable values for the $\mathrm{Zn}$ concentrations in the EPF of apparently healthy subjects ranging from young adult males to elderly persons, as well as in the EPF of patients with prostatitis.

The range of means of $\mathrm{Zn}$ concentration reported in the literature for normal EPF varies widely from $47.1 \mathrm{mg} / \mathrm{L}^{[43]}$ to 825 $\mathrm{mg} / \mathrm{L}^{[55]}$ with median of means $501 \mathrm{mg} / \mathrm{L}$ (Table 1 ).

In present study, 11 articles studied the effect of prostate inflammation on the Zn concentration of EPF (Table 2). All of the 11 articles studied the impact of inflammation on $\mathrm{Zn}$ concentration in EPF reported that there was a decrease of $\mathrm{Zn}$ level. In nine of the 11 articles were found that the decrease of $\mathrm{Zn}$ level was statistical significant and only two studies showed the relatively small and non-statistical significant decrease ${ }^{[29,30]}$. In two studies conducted by Kavanagh et al. ${ }^{[52]}$ and Gómez et al. ${ }^{[56]}$, it was observed that means of $\mathrm{Zn}$ concentration in EPF of inflamed prostates were almost 7 and 9 times, respectively, lower than in control group. However, in other studies the difference between patients with prostatitis and normal controls was lower and did not exceed 23$74 \%$.

The range of means of $\mathrm{Zn}$ concentration reported in these 11 articles for normal EPF varies from $220 \mathrm{mg} / \mathrm{L}$ to $825 \mathrm{mg} / \mathrm{L}^{[55]}$, with median of means $559 \mathrm{mg} / \mathrm{L}$ (Table 2). However, the range of means of $\mathrm{Zn}$ concentration for EPF of untreated prostatitis varies widely from $56 \mathrm{mg} / \mathrm{L}^{[56]}$ to $491 \mathrm{mg} / \mathrm{L}^{[55]}$, with median of means $268 \mathrm{mg} / \mathrm{L}$ (Table 2). Thus, the obtained median of means for $\mathrm{Zn}$ concentration in normal human prostatic fluid is about 2 times lower than median of mean values of the element content in prostatic fluid of inflamed prostate. In other words, the analysis of 11 studies with discordant data regarding prostatic fluid concentration of $\mathrm{Zn}$ demonstrated that there is a significantly diminished concentration of $\mathrm{Zn}$ in EPF of patients with prostatitis compared to controls. It is, therefore, reasonable to assume that $\mathrm{Zn}$ levels in EPF can reflect the role of this metal in the prostatitis etiology.

As indicated above, the range of means of $\mathrm{Zn}$ concentration reported in the literature for normal EPF and for EPF of untreated inflamed prostate varies widely. This can be explained by a dependence of $\mathrm{Zn}$ content on many factors, including age, ethnicity, mass of the gland, and others. Not all these factors were strictly controlled in cited studies. However, published data allowed us to estimate the effect of age at $\mathrm{Zn}$ concentration in EPF of normal prostate. In one study a significant increase in $\mathrm{Zn}$ concentration with increasing of age was shown by the Pearson's coefficient of correlation between age and $\mathrm{Zn}$ concentration in $\mathrm{EPF}^{[58]}$. According this study $\mathrm{Zn}$ concentration in EPF of apparently healthy men aged 41-82 years was about $20 \%$ higher than in age from 18 to 40 years. But this finding does not agree with other published data. For example, in the first quantitative $\mathrm{XRF}$ analysis of $\mathrm{Zn}$ concentration in EPF of 8 apparently healthy men aged 25-55 years no significant variation with age was recognized, in spite of no any statistical treatment of results was done in this investigation ${ }^{[42]}$. Fair and Cordonnier ${ }^{[48]}$ did not find any changes in the metal level with age using AAS for $\mathrm{Zn}$ measurement in EPF specimens obtained from 63 normal male subjects in age from 24 to 76 years. The conclusion was followed from the level of differences between the mean $\mathrm{Zn}$ results for three age groups evaluated by parametric Student's t-test. Additionally, $\mathrm{Zn}$, concentration in prostatic fluid showed no age relationship in the study of Kavanagh et al. ${ }^{[52]}$ when 35 specimens obtained from normal male subjects in age from 15 to 85 years were measured by AAS and the Pearson correlation between age and $\mathrm{Zn}$ concentration was used. It is, therefore, reasonable to assume that $\mathrm{Zn}$ level in EPF do not change with age or, at least, slightly increase in age above 40 years.

Another and, in our opinion, leading cause of inter-observer variability was insufficient quality control of results in these studies. In many reported papers such destructive analytical methods as AAS and ICP-AES were used. These methods need in an acid digestion of samples under high temperature. There is evidence that by use of these methods some quantities of TEs, including $\mathrm{Zn}$, are lost as a result of this treatment ${ }^{[62-64]}$. On the other hand, TEs of chemicals used for the acid digestion can contaminate the EPF samples. XRF and, particularly, EDXRF is a fully instrumental and non-destructive method because a drop of EPF is investigated without requiring any sample pretreatment or its consumption ${ }^{[65]}$.

In present study, in 14 articles $\mathrm{Zn}$ concentration in EPF samples was determined by the destructive analytical methods (13 articles - AAS and 1 articles - ICP-AES) and in 9 articles nondestructive analytical methods were used for this purpose (2 articles - XRF and 7 articles - EDXRF). Thus, published data allowed us to estimate the effect of acid digestion on the results of $\mathrm{Zn}$ determination in EPF on normal prostates (Tables 3 and 4). In articles with destructive analytical methods the range of means for $\mathrm{Zn}$ concentration in EPF of normal prostates varied from $220 \mathrm{mg} / \mathrm{L}$ to $825 \mathrm{mg} / \mathrm{L}$ (ratio $\mathrm{M}_{\max } / \mathrm{M}_{\min }=3.75$ ), with median of means 453 $\mathrm{mg} / \mathrm{L}$ (Table 3). The articles with nondestructive analytical methods have the rather narrow range of means for $\mathrm{Zn}$ concentration in EPF of normal prostates from $490 \mathrm{mg} / \mathrm{L}$ to 598 $\mathrm{mg} / \mathrm{L}$ (ratio $\mathrm{M}_{\max } / \mathrm{M}_{\min }=1.22$ ), with median of means $580 \mathrm{mg} / \mathrm{L}$. Thus, median of means for $\mathrm{Zn}$ concentration in EPF of normal prostates obtained by destructive analytical methods is $22 \%$ lower than that obtained by nondestructive methods. It is, therefore, reasonable to conclude that the choice of analytical method and quality control of results are very important factors for using the $\mathrm{Zn}$ concentration in EPF as biomarker of prostate diseases.

Table 3: Reference data of $\mathrm{Zn}$ concentration in normal prostatic fluid investigated by destructive AAS and ICP-AES methods

\begin{tabular}{|l|l|l|l|l|}
\hline Reference & Method & $\mathbf{n}$ & $\begin{array}{l}\text { Age, years } \\
\text { M(Range) }\end{array}$ & $\begin{array}{l}\text { Zn, mg/L } \\
\text { M } \pm \text { SD }\end{array}$ \\
\hline Marmar et al $1975^{[44]}$ & AAS & 33 & - & $451 \pm 215$ \\
\hline
\end{tabular}




\begin{tabular}{|c|c|c|c|c|}
\hline Anderson\&Fair, $1976^{[45]}$ & AAS & 15 & $50(30-74)$ & $352 \pm 190$ \\
\hline Fair et al $1976^{[46]}$ & AAS & 49 & $52(24-76)$ & $455 \pm 208$ \\
\hline Paz et al $1977^{[47]}$ & AAS & 53 & - & $299 \pm 202$ \\
\hline Fair\&Cordonnier $1978^{[48]}$ & AAS & 63 & $52(24-76)$ & $455 \pm 208$ \\
\hline Homonnai et al $1978^{[49]}$ & AAS & 12 & - & $335 \pm 45$ \\
\hline Marmar et al $1980^{[50]}$ & AAS & 33 & - & $451 \pm 215$ \\
\hline Kavanagh et al $1982^{[52]}$ & AAS & 35 & 49.2 & 580 \\
\hline Kavanagh $1983^{[53]}$ & AAS & 152 & - & $595 \pm 222$ \\
\hline Mo et al $2000^{[54]}$ & ICP-AES & 25 & $57.4 \pm 6.8$ & 305 \\
\hline Cai et al. $2002 *{ }^{[55]}$ & AAS & 22 & - & $220 \pm 85$ \\
\hline Gómez et al $2007^{[56]}$ & AAS & 10 & $44(40-62)$ & $519 \pm 374$ \\
\hline Zhuang et al. 2009* ${ }^{[55]}$ & AAS & 20 & - & $802 \pm 39$ \\
\hline He et al. $2013^{*[55]}$ & AAS & 40 & - & $825 \pm 71$ \\
\hline Median of means, mg/L & \multicolumn{4}{|l|}{453} \\
\hline Range of means $\left(\mathrm{M}_{\min }-\mathrm{M}_{\max }\right), \mathrm{mg} / \mathrm{L}$ & \multicolumn{4}{|l|}{$220-825$} \\
\hline Ratio $\mathrm{M}_{\max } / \mathrm{M}_{\min }$ & \multicolumn{4}{|c|}{$(825 / 220)=3.75$} \\
\hline
\end{tabular}

* Data of Chinese researches taken from the review Cui et al 2015

$M$-arithmetic mean, SD - standard deviation of mean, AAS - atomic absorption spectrophotometry, ICPAES - inductively coupled plasma atomic emission spectrometry

Table 4: Reference data of $\mathrm{Zn}$ concentration in normal prostatic fluid investigated by nondestructive XRF and EDXRF methods

\begin{tabular}{|c|c|c|c|c|}
\hline Reference & Method & $\mathbf{n}$ & $\begin{array}{l}\text { Age, years } \\
\text { M(Range) }\end{array}$ & $\begin{array}{l}\mathrm{Zn}, \mathrm{mg} / \mathrm{L} \\
\mathrm{M} \pm \mathrm{SD}\end{array}$ \\
\hline Birnbaum et al $1961^{[41]}$ & $\mathrm{XRF}$ & - & - & 490 \\
\hline Mackenzie et al $1962^{[42]}$ & XRF & 8 & $37(25-55)$ & $490 \pm 130$ \\
\hline Zaichick et al $1981^{[29]}$ & EDXRF & 15 & - & $580 \pm 183$ \\
\hline Zaichick et al $1996^{[30]}$ & EDXRF & 22 & $49(22-75)$ & $590 \pm 210$ \\
\hline Costello\&Franklin $2009^{[57]}$ & EDXRF & 24 & - & 588 \\
\hline Zaichick\&Zaichick $2018^{[58]}$ & EDXRF & 41 & $18-82$ & $573 \pm 202$ \\
\hline & & 13 & $28(18-40)$ & $501 \pm 47$ \\
\hline & & 38 & $59(41-82)$ & $598 \pm 34$ \\
\hline Zaichick\&Zaichick $2018^{[59]}$ & EDXRF & 42 & $31-75$ & $559 \pm 204$ \\
\hline Zaichick\&Zaichick $2018^{[60]}$ & EDXRF & 38 & $41-82$ & $598 \pm 207$ \\
\hline Zaichick\&Zaichick $2018^{[61]}$ & EDXRF & 38 & $41-82$ & $598 \pm 207$ \\
\hline Median of means, mg/L & \multicolumn{4}{|l|}{580} \\
\hline Range of means $\left(\mathrm{M}_{\min }-\mathrm{M}_{\max }\right), \mathrm{mg} / \mathrm{L}$ & \multicolumn{4}{|l|}{$490-598$} \\
\hline Ratio $\mathrm{M}_{\max } / \mathrm{M}_{\min }$ & \multicolumn{4}{|c|}{$(598 / 490)=1.22$} \\
\hline
\end{tabular}

$M$-arithmetic mean, $S D$ - standard deviation of mean, XRF - X-ray fluorescence, EDXRF - energy dispersive X-ray fluorescence

There is some limitation in our study, which need to be taken into consideration when interpreting the results of this review. The sample size of each study was relatively small, and a total of 285 patients with prostatitis and about 900 normal controls were investigated from all 25 studies. As such, it is hard to make definitive conclusions about the clinical value of the $\mathrm{Zn}$ concentration in EPF as biomarker of prostatitis.

\section{Conclusions}

The present study is a comprehensive study regarding the determination of $\mathrm{Zn}$ concentration in EPF as a biomarker for prostatitis. The study has demonstrated that $\mathrm{Zn}$ concentration levels are typically decreased in EPF samples of patients with prostatitis. The present study also demonstrates that EPF samples could be considered a reliable source for $\mathrm{Zn}$ biomarker analysis. Because of high heterogeneity, we recommend other primary studies.

\section{Ethics approval and consent to participate}

Not applicable.

\section{List of abbreviations}

www.ijirms.in
$\mathrm{CP}$, chronic prostatitis; TE, trace element; EPF, expressed prostatic fluid; AAS, atomic absorption spectrophotometry; ICPAES, inductively coupled plasma atomic emission spectrometry; XRF, $\mathrm{X}$-ray fluorescence analysis; EDXRF, energy dispersive X-ray fluorescent microanalysis.

\section{Conflicts of Interest}

None

\section{Authors' contributions}

SZ analyzed and interpreted the data regarding the normal and inflamed prostate. VZ analyzed and interpreted the data regarding the analytical methods, and was a major contributor in writing the manuscript. All authors read and approved the final manuscript.

\section{References}

[1] Krieger JN, Lee SW, Jeon J, et al. Epidemiology of prostatitis. Int J Antimicrob Agents. 2008;31(Suppl. 1):S85-90 
[2] Nickel JC. Prostatitis. Can Urol Assoc J. 2011;5(5):30615.

[3] Smith CP. Male chronic pelvic pain: An update. Indian J Urol. 2016;32(1):34-9.

[4] Chen Y, Li J, Hu Y, et al. Multi-factors including inflammatory/immune, hormones, tumor-related proteins and nutrition associated with chronic prostatitis $\mathrm{NIH}$ IIIa+b and IV based on FAMHES project. Scientific Reports. 2017;7:Article number 9143. Available from: https://www.nature.com/articles/s41598-017-09751-8

[5] Zaichick V. INAA and EDXRF applications in the age dynamics assessment of $\mathrm{Zn}$ content and distribution in the normal human prostate. J Radioanal Nucl Chem. 2004;262:229-34.

[6] Zaichick V, Zaichick S. The effect of age on $\mathrm{Br}, \mathrm{Ca}, \mathrm{Cl}$, $\mathrm{K}, \mathrm{Mg}, \mathrm{Mn}$, and $\mathrm{Na}$ mass fraction in pediatric and young adult prostate glands investigated by neutron activation analysis. Appl Radiat Isot. 2013;82:145-51.

[7] Zaichick V, Zaichick S. INAA application in the assessment of $\mathrm{Ag}, \mathrm{Co}, \mathrm{Cr}, \mathrm{Fe}, \mathrm{Hg}, \mathrm{Rb}, \mathrm{Sb}, \mathrm{Sc}, \mathrm{Se}$, and $\mathrm{Zn}$ mass fraction in pediatric and young adult prostate glands. J Radioanal Nucl Chem. 2013;298(3):1559-66.

[8] Zaichick V, Zaichick S. NAA-SLR and ICP-AES Application in the assessment of mass fraction of chemical elements in pediatric and young adult prostate glands. Biol Trace Element Res. 2013;156(1):357-66.

[9] Zaichick V, Zaichick S. Use of neutron activation analysis and inductively coupled plasma mass spectrometry for the determination of trace elements in pediatric and young adult prostate. Am J Analyt Chem. 2013;4:696-706.

[10] Zaichick V, Zaichick S. Relations of bromine, iron, rubidium, strontium, and zinc content to morphometric parameters in pediatric and nonhyperplastic young adult prostate glands. Biol Trace Element Res. 2014;157(3):195-204.

[11] Zaichick V, Zaichick S. Relations of the neutron activation analysis data to morphometric parameters in pediatric and nonhyperplastic young adult prostate glands. Advances in Biomedical Science and Engineering. 2014;1(1):26-42.

[12] Zaichick V, Zaichick S. Relations of the Al, B, Ba, Br, $\mathrm{Ca}, \mathrm{Cl}, \mathrm{Cu}, \mathrm{Fe}, \mathrm{K}, \mathrm{Li}, \mathrm{Mg}, \mathrm{Mn}, \mathrm{Na}, \mathrm{P}, \mathrm{S}, \mathrm{Si}, \mathrm{Sr}$, and $\mathrm{Zn}$ mass fractions to morphometric parameters in pediatric and nonhyperplastic young adult prostate glands. BioMetals. 2014;27(2):333-48.

[13] Zaichick V, Zaichick S. The distribution of 54 trace elements including zinc in pediatric and nonhyperplastic young adult prostate gland tissues. Journal of Clinical and Laboratory Investigation Updates. 2014;2(1):1-15.

[14] Zaichick V, Zaichick S. Androgen-dependent chemical elements of prostate gland. Androl Gynecol: Curr Res. 2014;2:2.

[15] Zaichick V, Zaichick S. Differences and relationships between morphometric parameters and zinc content in nonhyperplastic and hyperplastic prostate glands. British Journal of Medicine and Medical Research. 2015;8(8):692-706.

[16] Zaichick V., Sviridova T., Zaichick S. Zinc in the human prostate gland: normal, hyperplastic and cancerous. Int Urol Nephrol. 1997;29(5):565-74.
[17] Zaichick V, Zaichick S. Trace element levels in prostate gland as carcinoma's markers. Journal of Cancer Therapy. 2017;8:131-45.

[18] Zaichick V, Zaichick S. Ratios of selected chemical element contents in prostatic tissue as markers of malignancy. Hematol Med Oncol. 2016;1(2):1-8.

[19] Zaichick V, Zaichick S. Ratios of Zn/trace element contents in prostate gland as carcinoma's markers. Cancer Rep Rev. 2017;1(1):1-7.

[20] Zaichick V, Zaichick S. Ratios of selenium/trace element contents in prostate gland as carcinoma's markers. J Tumor Med Prev. 2017;1(2):555556

[21] Zaichick V, Zaichick S. Ratios of rubidium/trace element contents in prostate gland as carcinoma's markers. Can Res and Clin Oncology. 2017;1(1):13-21.

[22] Zaichick V, Zaichick S. Ratios of cadmium/trace element contents in prostate gland as carcinoma's markers. Canc Therapy and Oncol Int J. 2017;4(1):555626.

[23] Zaichick V, Zaichick S. Ratios of cobalt/trace element contents in prostate gland as carcinoma's markers. The International Journal of Cancer Epidemiology and Research. 2017;1(1):21-27.

[24] Zaichick V, Zaichick S. Ratios of calcium/trace elements as prostate cancer markers. J Oncol Res Ther. 2017;(4): J116.

[25] Zaichick V, Zaichick S. Ratios of $\mathrm{Mg} /$ trace element contents in prostate gland as carcinoma's markers. SAJ Canc Sci. 2017;2(1):102.

[26] Zaichick V. The prostatic urethra as a Venturi effect urine-jet pump to drain prostatic fluid. Med Hypotheses. 2014;83:65-8

[27] Mackenzie AR, Hall T, Whitmore WFJr. Zinc content of expressed human prostate fluid. Nature (London). 1962;193(4810):72-3.

[28] Marmar JL, Katz S, Praiss DE, et al. Values for zinc in whole semen, fraction of split ejaculate and expressed prostatic fluid. Urology. 1980;16(5):478-80.

[29] Zaichick V, Tsyb A, Dunchik VN, et al. Method for diagnostics of prostate diseases. Certificate of invention No 997281 (30.03.1981), 1981, Russia.

[30] Zaichick V, Sviridova T, Zaichick S. Zinc concentration in human prostatic fluid: normal, chronic prostatitis, adenoma, and cancer. Int Urol Nephrol. 1996;28(5):68794.

[31] Al-Ebraheem A, Farquharson MJ, Ryan E. The evaluation of biologically important trace metals in liver, kidney and breast tissue. Appl Radiat Isot. 2009;67(3):470-4.

[32] Hennigar SR, Kelley AM, McClung JP. Metallothionein and zinc transporter expression in circulating human blood cells as biomarkers of zinc status: a systematic review. Adv Nutr. 2016;7(4):735-46.

[33] Hartwig A. Recent advances in metal carcinogenicity. Pure Appl Chem. 2000;72(6):1007-14.

[34] Schrauzer G.N. Antioxidant supplementation increases skin cancer risk, or, why zinc should not be considered an antioxidant. J Nutr. 2008;13 (4):821-2.

[35] Grigorescu R, Gruia MI, Nacea V, et al. Parameters of oxidative stress variation depending on the concentration of inorganic zinc compounds. J Med Life. 2015;8(4):44951 .

[36] Schwartz MK. Role of trace elements in cancer. Cancer Res. 1975;35:3481-7. 
[37] Zaichick V. Medical elementology as a new scientific discipline. J Radioanal Nucl Chem. 2006;269:303-9.

[38] Ihsan AU, Khan FU, Khongorzul P, et al. Role of oxidative stress in pathology of chronic prostatitis/chronic pelvic pain syndrome and male infertility and antioxidants function in ameliorating oxidative stress. Biomed Pharmacother .2018;106:71423.

[39] Paulis G. Inflammatory mechanisms and oxidative stress in prostatitis: the possible role of antioxidant therapy. Res Rep Urol. 2018;10:75-87.

[40] Zhao H, Shen JH, Chen YP, et al. Changes of seminal parameters, zinc concentration and antibacterial activity in patients with non-inflammatory chronic prostatitis/chronic pelvic pain syndrome. Zhonghua Nan Ke Xue. 2008;14(6):530-2.

[41] Birnbaum D., Hall T., Lee R. Zinc content of rat sperm cells from ejaculate, vas, spididymis and testis. Pros Soc Exper Biol Med. 1961;108(2):321-4.

[42] Mackenzie AR, Hall T, Whitmore WFJr. Zinc content of expressed human prostate fluid. Nature (London). 1962;193(4810):72-3.

[43] Burgos MH. Biochemical and functional properties related to sperm metabolism and fertility. In: Male accessory sex organs (Ed.: Brandes D.) Academic press, New York, 1974, pp.151-160.

[44] Marmar JL, Katz S, Praiss DE, et al. Semen zinc levels in infertile and post vasectomy patients and partients with prostatitis. Fertil Steril. 1975;26(11):1057-63.

[45] Anderson RU, Fair WR. Physical and chemical determinations of prostatic secretion in benign hyperplasia, prostatitis, and adenocarcinoma. Invest Urol. 1976;2):137-40.

[46] Fair WR, Couch J, Wehner N. Prostatic antibacterial factor. Identity and significance. Urology. 1976;7(2):16977.

[47] Paz G, Sofer A, Homonnai TZ, et al. Human semen analysis. Seminal plasma and prostatic fluid composition and their interrelations with sperm quality. Int J Fertil. 1977;22:140-7.

[48] Fair WR, Cordonnier JJ. The $\mathrm{pH}$ of prostatic fluid: A reappraisal and therapeutic implications. $\mathrm{J}$ Urol. 1978;120(6):695-8.

[49] Homonnai ZT, Matzkin H, Fainman N, Paz G, Kraicer $\mathrm{PF}$. The cation composition of the seminal plasma and prostatic fluid and its correlation to semen quality. Fertil Steril. 1978;29(5):539-42.

[50] Marmar JL, Katz S, Praiss DE, et al. Values for zinc in whole semen, fraction of split ejaculate and expressed prostatic fluid. Urology. 1980;16(5):478-80.

[51] Zaneveld LJD, Tauber PF. Contribution of prostatic fluid components to the ejaculate. In: Prostatic Cell: Structure and Function. (Eds.: Murphy G.P., Sandberg A.A., Karr J.P.). Alan R. Liss, New York, 1981, part A, pp. 265277.
[52] Kavanagh JP, Darby C. The interrelationships between acid phosphatase, aminopeptidase, diamine oxidase, citric acid, $\beta$-glucuronidase, $\mathrm{pH}$ and zinc in human prostate fluid. Int J Androl. 1982;5:503-12.

[53] Kavanagh JP. Zinc binding properties of human prostatic tissue, prostatic secretion and seminal fluid. J Reprod Fert. 1983;68(2):359-63.

[54] Mo Z-N, Huang W-H, Chen J, et al. Early and late longterm effects of vasectomy on $\mathrm{Zn}, \mathrm{Cd}$, and $\mathrm{Cu}$ levels in prostatic fluid and serum. Asian J Androl. 2000;2:121-4.

[55] Cui D, Han G, Shang Y, et al. The effect of chronic prostatitis on zinc concentration of prostatic fluid and seminal plasma: a systematic review and meta-analysis. Curr Med Res Opin. 2015;31(9):1763-9.

[56] Gomes Y, Arocha F, Espinoza F, et al. Zinc levels in prostatic fluid of patients with prostate pathologies. Invest Clin. 2007;48(3):287-94.

[57] Costello LC, Franklin RB. Prostatic fluid electrolyte composition for the screening of prostate cancer: a potential solution to a major problem. Prostate Cancer Prostate Dis. 2009;12(1):17-24.

[58] Zaichick V, Zaichick S. Effect of age on the Br, Fe, Rb, $\mathrm{Sr}$, and $\mathrm{Zn}$ concentrations in human prostatic fluid investigated by energy-dispersive X-ray fluorescent microanalysis. MicroMed. 2018;6(2):94-104.

[59] Zaichick V, Zaichick S. Some trace element contents and ratios in prostatic fluids as ancillary diagnostic tools in distinguishing between the benign prostatic hyperplasia and chronic prostatitis. Archives of Urology. 2019;2(1):12-20.

[60] Zaichick V, Zaichick S. Significance of trace element quantities in the prostatic secretion of patients with chronic prostatitis and prostate cancer. Journal of Biomedical Research and Reviews. 2019;2(1):56-61.

[61] Zaichick V, Zaichick S. Br, Fe, Rb, Sr, and Zn Levels in the Prostatic Secretion of Patients with Chronic Prostatitis. Int Arch Urol Complic. 2018;4:046.

[62] Zaichick V. Sampling, sample storage and preparation of biomaterials for INAA in clinical medicine, occupational and environmental health. In: Harmonization of HealthRelated Environmental Measurements Using Nuclear and Isotopic Techniques. IAEA, Vienna, 1997, pp. 123-133.

[63] Zaichick V, Zaichick S. A search for losses of chemical elements during freeze-drying of biological materials. J Radioanal Nucl Chem. 1997;218(2):249-53.

[64] Zaichick V. Losses of chemical elements in biological samples under the dry aching process. Trace Elements in Medicine. 2004;5(3):17-22.

[65] Zaichick V, Zaichick S, Davydov G. Method and portable facility for measurement of trace element concentration in prostate fluid samples using radionuclide-induced energy-dispersive X-ray fluorescent analysis. Nucl Sci Tech. 2016;27(6):1-8. 